\title{
Outsourcing Equality: Migrant Care Worker Imaginary in Finnish Media
}

\section{Camilla Nordberg'}

Dr. Soc. Sc., Academy of Finland Research Fellow, Senior Lecturer in Social Work and Social Policy, Swedish School of Social Science, University of Helsinki, Finland

\begin{abstract}
Implications from the restructuring of Nordic eldercare include the incorporation of new categories of care workers and a redefinition of the terms of citizenship and participation in working life. Drawing on the idea that policy actors script care worker subjectivities, this article examines print media as a key arena where the cultural imaginary of care work is played out. The media has the potential to accommodate ideological complexity through the possible range of participatory actors. From the scripts promoted through the mediascape, we can learn about the positions understood as being (in)appropriate for migrant care workers. This study draws on the analysis of news and feature stories from 2003 to 2013 in the largest Finnish daily, Helsingin Sanomat, and in the periodical Kuntalehti, published by the Finnish Association of Local and Regional Authorities. The article points to tensions in Finnish media discourse, identifying ambiguous occupational scripts for migrant care workers - rooted in neoliberal repertoires of self-sufficiency and normative individualism on the one hand and helplessness and naivety on the other hand. It draws attention to an unsettling construction whereby migrant care workers are excluded from a long-term contract with the Finnish care labor market, and where social equality is conditioned to global redistribution.
\end{abstract}

\section{KEY WORDS}

Eldercare / Finland / flexible citizenship / gender / media / migration / migrant care workers / neoliberalism / Nordic welfare state / working life

DOI

10.19154/njwls.v6i3.5530

\section{Introduction}

vast body of scholarly literature has illustrated how care labor migration from the global south to the global north gives rise to gendered and ethnicized care chains (Hochshild, 2000; Lutz \& Palenga-Möllenbeck, 2012; Parreñas, 2000), generating care gaps in less-resourced countries (Yeates, 2009), and constituting new forms of global inequality and subordination in migrants' working life (Dahle \& Seeberg, 2013; Doyle \& Timonen, 2009; Laurén \& Wrede, 2008; Olakivi, 2013; van Riemsdijk, 2010). Internationally, research on migrant care workers has largely focused on domestic, private, and informal care by 'low skilled' workers (Anderson, 2007; Lutz, 2008; Näre, 2013), mostly due to the comparatively recent systematic recruitment of migrant workers to Northern European care regimes with a higher level of institutional

\footnotetext{
${ }^{1}$ E-mail: camilla.nordberg@helsinki.fi
} 
care arrangements. Nevertheless, during the last decade, there has been rising concern about the sustainability of public care, particularly eldercare, also in this region. In Finland, which constitutes the empirical site of this study, rapid demographic change and a devaluation of care work have triggered political anxiety about the availability of care labor in the near future. Solutions are sought among the long-term unemployed in general, unemployed newcomer residents, and 'imported' care labor.

While complex welfare systems currently share the experience of a diversifying care work force, the restructuring of care has to be analyzed at the national and local levels, while remaining attached to specific political-institutional practices and local discourses (see also Kröger, 2011; Williams, 2012; Wrede \& Näre, 2013). The contemporary local context of Finnish eldercare is featured by increasingly neoliberal governance and New Public Management (NPM) doctrines, characterized by an 'ambiguity of the welfare state and the competition state' (Kettunen, 2011: p. 38). On the one hand, the very notion of a 'welfare state' is almost disappearing from political discourse, giving way to a hegemonic language of the economy, regarding cost-efficiency and individualization (Isaksen, 2010; Kananen, 2014; Kantola \& Kananen, 2013). When identifying a deep transformation and marketization of the (elder) care regime in Finland, Anneli Anttonen and Liisa Häikiö argue that 'Finland seems to be approaching the form of a liberal welfare state' with a stronger emphasis on commodification, consumerism, and freedom of choice (Anttonen \& Häikiö 2011: p. 70). Eldercare services are currently being outsourced to both profit and nonprofit care work providers (Anttonen \& Häikiö, 2011; Brennan et al., 2012; Dahl, 2012; Kamp \& Hvid, 2012). On the other hand, there is still strong citizen support for the collectively funded, public, universal, and egalitarian welfare arrangements that have been characteristic for the Nordic countries (Edlund \& Johansson, Muuri \& Manderbacka, 2010; Sevä, 2013; Svallfors, 2013).

Here, the notion of neoliberalism is understood as a mobile logic of governing that is selectively applied in different contexts, rather than as a fixed predetermined concept (Ong, 2007). It has been argued that policy-makers in a neoliberal context employ legitimatizing practices to draw on a moral consensus (Kettunen, 2012: p. 38). In the case of migrant care workers, for example, this does not imply that everyone 'thinks the same' about incorporating migrant workers. Rather, the implication is that a certain consensus is produced through which different actors make sense of care, welfare, and immigration. Such sense-making has to resonate with the complex implementation of neoliberalism locally. That is, local political discourse has to accommodate the ideological ambiguity of welfare stateism and neo-liberalizaton in its consensus-building practices referred to above.

The aim of this paper is to explore the ways in which the media-and different actors voiced in the media-script migrant care worker subjectivities in the context of restructuring eldercare governance. Scripts are here understood as those implicit and explicit cultural repertoires used by policy actors to position migrant care workers in specific ways (Wrede, 2014). Hence, analytically, scripts are particularly valuable for illuminating the ways in which different national and local contexts make specific repertoires available (or not). Through such repertoires, stigmatized groups may be enabled dignity, a sense of recognition and belonging (Hallgrímsdottir et al., 2008; Lamont et al., 2013; Nordberg, 2007, 2015). Sirpa Wrede argues that the complex multilevel coordination processes and steering of care work organization in the context of neoliberal governance is based on scripting flexible, narrow work roles. Care workers, 
regardless of their formal credentials and former work experience, are treated as nonexpert labor in the Finnish labor market (Wrede, 2014). In the neoliberal innovationcentered context, floor-level care is considered to be simple work for which human labor can be sought from previously unrecognized low-skilled labor pools (Wrede et al., 2013). One of the central arenas where the cultural transformation of care work occurs is in the print media, which is approached in the empirical section of the paper.

\section{Producing flexible citizens}

Encoded within nation-state based citizenship regimes is 'a paradigmatic representation of identities, of the national as well as the model citizen, the second-class citizen, and the noncitizen' and 'representations of proper and legitimate social relations among and within these categories' (Dobrowolsky \& Jenson, 2004: p. 156). Thus, a specific citizenship regime is constitutive of particular, intersectional subjectivities, which are constantly being renegotiated and redefined, increasingly in the context of different media (McCombs, 2004). From the scripts promoted in the mediascape-and from the moral reasoning mediated actors use to legitimatize these scripts-we can subsequently learn about changing citizenship regimes and shifting terms of participation.

The introduction established that the state approach to care work in Finland has been redefined in ways that reflect neoliberal ideas and result in complex new inequalities to be further explored in this article. This paper employs Aihwa Ong's (1999) discussion on flexible citizenship for the purposes of examining a key feature of the new inequalities, related to the position of migrant care workers. Ong (1996) engages in a critical dialogue with scholars who are one-sidedly concerned with claims-making practices by subordinated subjects. She conceptualizes citizenship as dialectically produced by the subjects and the broader cultural and institutional framework. Thus formulated, citizenship is understood as a cultural process of 'subjectification', in a Foucauldian manner of 'self-making and being made', whereby the 'cultural inscription of state power and other forms of regulation /.../ define the different modalities of belonging.' There is thus a need to examine how the location of different categories of subjects within the nation-state and within the globalizing economy shapes their citizenship (Ong, 1996: pp. 737-738).

Ong (1999: p. 6) introduces the concept of 'flexible citizenship' to refer to the 'cultural logics of capitalist accumulation, travel, and displacement that induce subjects to respond fluidly and opportunistically to changing political-economic conditions.' Hence, she elucidates the ways in which subjects in the global arena are regulated by practices of governance that favor 'flexibility, mobility and repositioning', and, how such practices are defined by specific understandings of 'family, gender, nationality, class mobility, and social power' (Ong, 1999: p. 6). Subsequently, in the neoliberal era, the relationship between the state and its citizens has changed and citizens are increasingly referred to as customers, consumers, or service users (Hasenfeld \& Garrow, 2012; Hvinden \& Johansson, 2007). Accordingly, in debates on migration, earlier emphasis on national security has been accompanied by logics of utility and specific and limited modes of integration (Carmel, 2011).

Ong's $(1999,2006)$ work and her conceptualization of flexible citizenship draws on the specific case of the high-skill Asian diaspora, looking into the ways in which wealthy 
highly educated migrants benefit from the potential to flexible mobility, occasionally even possessing multiple formal citizenship. Following Wrede's (2014) ideas about policy scripts, it could be argued that Ong's highly educated migrants fit the scripts aimed at attracting the so-called global talent for new globalizing knowledge economies. This contribution serves to expand the focus to the heterogeneous collective of migrant care workers; they do not represent a 'pure' category of high-skilled or low-skilled migrants. Rather, as elaborated below, the role assigned to them is activating fundamental contemporary tensions in global mobility between flexibility, individual self-sufficiency, reason, and freedom of choice on the one hand, and vulnerability and subordination on the other hand. This paper contributes to the literature on migrant care work by highlighting the ways in which the relocation of this specific category of migrants to a nation-state-with a strong legacy of egalitarian social policies-triggers a renegotiation of labor market equality and, ultimately, the terms pertaining to solidarity and citizenship participation.

This paper examines how contemporary migration imaginary and care work governance script care workers' subjectivities. The analytical focus is on print media owing to its possibility to incorporate ideological complexity through the range of actors potentially having access to them. The analysis reviews the ways in which the media-and different actors voiced in the media-morally legitimatize and/or neglect new hierarchies and inequalities in working life.

\section{Research methods and data: scripting migrant care workers in the Finnish media}

The media arguably have substantial power to define issues and to shape public reaction to them (McCombs, 2004; van Dijk, 1988). It has even been argued that in contemporary societies, 'everything' is mediated, that social processes can no longer be understood without acknowledging the role of the media (Livingstone, 2009). By adding the suffix 'scape' to the media, anthropologist Arjun Appadurai (1990) wants to highlight that scapes, rather than being objective relations, are 'deeply perspectival constructs, inflected very much by the historical, linguistic and political situatedness of different sorts of actors' (Appadurai, 1990: p. 296). Mediascapes refer both to the production and dissemination of information as well as to the images of the world created by these media. Appadurai's (1990) view of mediascapes coincides with the neo-institutionalist reading of scripts in policies (Wrede, 2014), in that mediascapes are:

Image-centered, narrative-based accounts of strips of reality, and what they offer to those who experience and transform them is a series of elements (such as characters, plots or textual forms) out of which scripts can be formed of imagined lives, their own as well as those of others living in other places. (Appadurai, 1990: p. 299)

The empirical analysis focused on the ways in which print media draft scripts for migrant care workers by, on the one hand, assigning them into specific social categories (e.g., migrant, professional, or mother) and, on the other hand, through legitimatizations, or normative assertions ascribed to these. The 'media voice' implies a broad range of actors. While the media itself is explicitly voiced in editorials and in some columns, various actors outside the media are the main sources for information and images created (Van Dijk, 1991).

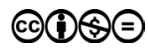


Moreover, elite actors and the general public are voiced in the opinion section. Although these voices and statements are in due course filtered by the press, the scripts introduced to the readers can be seen as a joint construction between external sources and the press (ter Wal, 2002). The social location of migrant care workers-as distanced from society at large-contributes to media imaginaries becoming a key site of public interaction with migrant care workers (cf. Hallgrímsdóttir et al., 2008). The analysis was conducted through a close inductive reading, tracing the claims, the moral legitimation of claims and hegemonic claims-making actors voiced by the press in interviews and opinion articles (Koopmans et al., 2005; Nordberg, 2004).

During the course of the analysis, notions of ambivalence in the promoted care worker scripts emerged which were of interest (cf. Sajoo, 2008). These will be further elaborated below. The media texts support the production of neoliberal subjectivities, joining in the complex multilevel governance of care work by helping to produce the taken-for-granted understanding of care work as low-skilled work that should be efficiently organized in line with market conditions (Wrede, 2014). Governmentality scholars have concluded that by "promoting and disseminating normative subjectivities, the state and other actors "govern at a distance" and "govern through freedom" (Laliberte Rudman, 2006: p. 186). Accordingly, to govern is to acknowledge the freedom of actors and to 'utilize it for one's own objectives' (Rose, 1999: p. 4).

The most important data source for the analysis is Helsingin Sanomat's (HS) coverage of migration and ethnicity related issues linked to eldercare between January 2003 and April 2013. An electronic text-searchable archive has been available from the year 2003. The data were initially compiled and quantitatively analyzed as part of a SwedishFinnish research collaboration (Torres et al., 2014). HS is the dominant Finnish daily and the largest Nordic daily. The paper states itself as being independent and nonaligned. The selection of stories from HS's internet archive was based on the criteria that eldercare was discussed in a direct relation with any of the following elements: migration, ethnicity, minority, foreigner, culture, multiculturalism, diversity, and language, including derivatives. ${ }^{2}$ By including a wide range of search terms, the aim was to secure the largest possible number of relevant articles. Particularly during the first years of the time period, migrants are occasionally referred to as foreigners or cultural minorities. The initial search in the electronic HS archive resulted in 2310 articles, out of which 224 were classified as relevant for the purpose of the study. The final selection includes news articles, feature articles, editorials, and letters to the editor. It does not contain briefs about TV-programs or public events, nor stories focusing on elder people or aging in general, outside the care context. Furthermore, the data include 41 articles in Kuntalebti, comprising a total sample of relevant texts from January 2003 to April 2013. Kuntalehti is a bimonthly paper published by the Association of Local and Regional Authorities. ${ }^{3}$ Kuntalehti was included in the study, as care for the elder remains the responsibility of local authorities (municipalities) in Finland, even though neoliberal reforms are redefining and fundamentally narrowing down that responsibility.

\section{Results: Scripting ambiguous care worker subjectivities}

The analysis illustrates tensions in the Finnish media discourse. It identifies a combination of scripts of wanted, entrepreneurial, and qualified care worker subjectivities and 
scripts of naive and low-skilled carers who are 'out-of-place.' It sees these ambiguous scripts as rooted in neoliberal repertoires centered on normative individualism and apolitical achievement. It brings attention to an unsettling construction whereby migrant care workers are excluded from a long-term contract with the Finnish care labor market.

\section{Weather vanes of the market economy}

The voiced actors identified in the data consist of, first and foremost, the media itself, through editorials, columns, 'hard' news, and feature articles, and second, the various bodies representing the employers-employer organizations, recruitment companies, the Confederation of Finnish Industries (EK), the National Bureau of Statistics, and some government agencies such as the Government Institute for Economic Research (VATT) and the National Institute of Welfare and Health (THL; previously known as Stakes). The main story about the transformations of Finnish eldercare offered to the Finnish audience during this time has been a 'common sense' urgency to actively import care labor (Nordberg, 2012; Wrede \& Näre, 2013), mainly from the Philippines, to some extent from China and Spain where care workers appear to be readily available. Migrants are 'needed' both as care workers and as tax-payers:

In a recent inquiry on the need for workers, the Government Institute for Economic Research predicts that Finland is rapidly developing into a care society. By the year 2025, the social and health care sector will need at least 80000 - if not as many as $120000-$ more people than today to care for people who have reached old age. Many are making predictions in Finland. For example, last autumn the National Bureau of Statistics estimated that, by 2025, Finland will need around one million migrants to maintain the current dependency ratio and service structure. (HS 12.4.2010)

The disparity in the numbers that are presented in the quote above effectively illustrates the sense of a rapid escalation in 'the need' for migrant workers, a rhetoric device that generates the impression of urgency and unpredictability. 'Necessity' rhetoric typically uses numbering and demographic statistics to produce common sense rationales on the need to ensure future economic growth (Nordberg, 2004). With regard to labor market policy, contemporary competitiveness subsequently involves the recruitment of workers with a recent migrant background primarily to secure the sustainability of the care work force. In this context, migrant care workers are not only a necessity but also a possibility, assessed according to their quality as smoothly recruited, motivated, and capable. Helsingin Sanomat uses mechanical catch phrases like 'New technology is needed and caring hands from abroad' (January 30, 2008). According to Hendriks \& Tops (1999), the economic efficiency that drove the first wave of neoliberal NPM reform in continental Europe in the 1980s was criticized for its lack of attention to democracy and citizen participation. A second wave of NPM reform in the 1990s then focused more on participation and interactive decision-making (Hedriks \& Tops, 1999). It has been suggested that the recent public management reforms in Finland have been 'somewhat akin to the first wave' (Häikiö, 2010: p. 366). Historically, it has not been difficult to legitimatize such an emphasis in politics. While the neoliberal transition has occurred later and been of a slightly different kind in northern Europe than in other 'western democracies', in 
Finland, it has been fuelled by a strong historical confidence in economic competitiveness as the basis for achieving welfare, social equality, and ultimately a sense of community (Kettunen, 2011). In media portrayal about the 'necessary importation' of paid care workers, the link between the competitive economy and a communitarian ethos is articulated through an overtly nationalist, protectionist discourse, whereby migrant workers are invited to the nation-state through their participation in the economy, and in a position as outsiders:

\begin{abstract}
It is important, that immigrants already residing in Finland are employed and that new immigrants are effectively educated /.../ Also the future integration of immigrants should be implemented according to national decisions and immigrants should respect European fundamental values. (Chair of the Association of Local and Regional Authorities, Pekka Nousiainen, Kuntalehti 27.2.2009)
\end{abstract}

The quote constitutes an example of how migrant othering is played out in the Finnish media by simply lumping together settled migrants and the newly arrived within a discourse of instrumentalist integration. Migrants are invited as part of the national welfare community primarily in positions as grantors of its future prosperity. This form of reasoning seems to offer a persuasive way to adapt global neoliberal models to the Nordic context. Tellingly, the word 'equality' appears 15 times and 'justice' eight times in the Helsingin Sanomat analysis, while 'competitiveness', 'efficiency', and 'flexibility' appear 71, 54, and 17 times, respectively. This being said, particularly in Finland, the egalitarian ethos of the welfare state has presumed a virtuous circle between social equality and economic austerity (Kettunen, 2011). Whereas social and economic arguments have not opposed one another, but rather presupposed one another, a semantic shift toward neoliberal discourse was arguably easier to apply. However, the very ideal of social citizenship and the rights/duties nexus was different in earlier decades of welfare stateism. In neo-liberal times, global economic competition more explicitly defines social contract negotiations (see, e.g., Kananen 2012).

Compared with political debates in general, the mediascape increasingly relies on personal, image-centered, narratives, potentially humanizing migration-related issues (Sowards \& Pineda, 2013). However, in the Finnish case presented here, individual narratives in feature stories are, in various ways, mirroring the macro-political agenda where the new landscape of care work is predominantly of interest from the nationalistic point of view of filling the 'care gap.' Migrant human stories are offered, but the individuals depicted also take roles as disciplined and hardworking. Their zealous workethic is often emphasized and almost glorified:

Maia's surname is Lillepöld, which means flower field in Finnish, but her colleagues at the nursing home Kustaankartano in Helsinki calls her 'Maia Mehiläinen' [nickname for being a hard worker - 'Maia the busy bee']. /.../ She is almost sad to have to take a day off every week. 'Work doesn't kill. Rather it kills you if you don't have a job. Then I get irritated. I become restless', says the lively Lillepöld. (HS 18.9.2011)

Ong (1999) illuminates the positioning of migrant care workers within a realm of flexible citizenship in the global economy as 'self-entrepreneurs.' Following Ong's analysis, neoliberal policy change is often accomplished by workers themselves who use 
transnational connections to generate resources not available to them within a single nation-state. The analysis of the media texts indeed shows how the mediascape scripts new kinds of commodified care worker subjectivities, agents selling their labor to the Finnish welfare state, compensated by money transfers (see also Pöyhtäri, 2014): 'Here I get paid ten times more than in the Philippines. I can provide my children with what they need' (HS 11.1.2009), says a nurse who had to migrate in order to provide for her children's university studies.

The media analysis shows how coming to Finland is, first and foremost, framed as an incredibly 'good deal' for new migrants. However, their mobility is conditioned in different ways.

\section{Displaced, de-professionalized, and de-politicized}

While migrant care workers move across state borders to take advantage of the global markets, their genuine mobility and flexibility of citizenship is restrained by various modes of subordination and limited choice on how to live their lives. Many of the professional nurses did not plan to move, but needed to ensure the housing and wellbeing of their families, by doing what many Finns would consider to be quite menial jobs. One experienced nurse working as a practical nurse explains:

It is difficult to be away, because I never planned to move abroad. I worked in the state hospital as a surgical nurse, in a maternity ward and an emergency ward. But when the children grew older and went to the university, it became too expensive /.../ I listen to love songs. After 18 years of marriage we are away from each other for the first time, my wife and I. A while ago our neighborhood flooded. So much water came though to our house that it reached the neck of my wife. It felt bad that I could do nothing to help her. (HS 11.1.2009)

As opposed to the hegemonic discourse found in the so-called hard news, a phase of active recruitment of Filipino nurses to eldercare in 2008 and 2009 was particularly inflated with individualized narratives. The narratives highlight the strong desire among the women, occasionally also men, to move across the globe in search for a better life for themselves, their families, and their broader community. Large-size images played a crucial role in mediating a sense of proximity in these feature stories, bringing attention to their actual life stories, their lives as located in specific places, and their travel between those places:

Circe has a nursing diploma and she found a job in Saudi Arabia. Circe went to the Middle East, worked hard in a hospital and sent money back to her parents. In the home village close to the city of Iloilo, the walls of a new house started to form. Later Circe left for Kuwait for two years. /.../ Her mother Elinda brings some bananas from their own tree to the table. Now there is hope for the family to get their home properly done. Circe is offered a job which will give her ten times higher salary than she would get working as a nurse in Iloilo. (HS 20.1.2008)

While such narratives potentially cultivate a form of counter-discourse to instrumentalist, hard news reporting, they simultaneously individualize responsibility. The construction 
of these professionals as global vagabonds, moving back and forth with no solid base of employment, implicitly presupposes a 'guest-worker model', whereby the nurses are not offered a more stable and long-term position on the regular Finnish labor market.

Nevertheless, truly counter-argumentative, critical voices also appear in the media analysis, particularly in letters to the editor and in feature stories. A return migrant, referring to herself in the third person, concludes that the current structures of shortterm jobs and poor working conditions are detrimental and create a position of permanent poverty: 'This return migrant is considering returning to where she came from in spring. Finland does not need her. The old and the sick do, but not Finland' (HS 17.11.2008). A reading of the media texts at the level of actors highlights a gendered and classed polarization of the public debate. Such polarization is illustrated by the dominance in the counter-discourse of female public sector employees and representatives from nonprofit organizations. The woman vice chair of the United Nations Population Fond concludes that:

The shortage of nurses has given rise to increased female migration. Migrant women are often employed in the low-pay service sector: they care for children, the sick and the elder. /.../ Receiving countries benefit from the labor, but for sending countries it may be a problem. An estimated 30-50 percent of the science and technology experts from developing countries live in the west. (HS 7.9.2006)

In another letter to the editor, two 'Finnish' female care work students are critical of the unreflective recruitment discourse: 'Immigrants have been proposed as a solution to the shortage of labor. However, this shortage is not a general issue. It is specifically related to low-income sectors, such as care work. It is absurd to imagine that all immigrants would like to be trained specifically as care workers.' (HS 20.4.2007)

The gendered polarization of the media debate between the female 'soft emotional intelligentsia' and the male 'responsible economy' is familiar from previous research on policy change in the media (e.g., Keskinen 2009). This way, hard news is constructed as the site of real politics, while personal narratives are de-politicized, decoupling migrant care workers from the more general political concerns related to the restructuring of eldercare work. Moreover, the poorly recognized professionalism of migrant background care workers is fuelled by the fact that public authorities and care managers are using racialized stereotypes about the caring 'nature' of women from some regions of the world for legitimatizing recruiting strategies from abroad (Cheng, 2004; Näre \& Nordberg, 2016; Parreñas, 2000). Such primordial discourse draws on claimed cultural advantages for carrying out this kind of bodily work rather than professional skills. The Director of the National Institute of Health and Welfare proposes in a column that 'Immigrants should be open-mindedly recruited for care work tasks. At the same time, it would generate a cultural import from countries where aging is respected' (HS 6.7.2003). Such 'culture talk' feeds the focus on the personal traits of migrant (women) care workers, typically as warm, kind, and happy, highlighting the private rather than the professional sphere of care workers:

In the nursing home in Oulunkylä, Taniform does everything: bathes, dresses, helps with going to the toilet, taking medicine and going to sleep. According to her fellow workers, Taniform has a natural respect for elder people that Finns also could learn from. Sometime 
she starts singing 'Two boys from Kurikka' is my own song, Taniform laughs in a clear Finnish language. (HS 14.5.2008)

The occupational subjectivity of the migrant background care worker seems to be conditioned also by a self-presentation as a 'naturally fit' carer and care work as a calling:

Nasro Yusuf qualified as a practical nurse last year. She worked in an apprenticeship in Kustaankartano (large eldercare institution in Helsinki) for three years and got a job from the same ward. 'Patients touch my hand and say, what a beautiful color, where have you been sunbathing, she says laughing' /.../ Yusuf describes Kustaankartanto as her second home: 'It is nice to work with people.' (HS 25.4.2010)

Such a biased return to forms of pre-modern carer subjectivities, when care work was seen as a vocation, calling, or mission in life, occurs simultaneously with care work in general in the Nordic countries becoming increasingly professionalized, with a stronger emphasis on paper-work, on verbal, and rhetoric skills (Boddy \& Cameron, 2006; Vabø, 2009).

Furthermore, professional misrecognition is fed by feature stories portraying migrant care workers as naïve, childish, and 'out of place': 'We have bought clothes here, coats and T-shirts from flea markets in Pasila and at Bulevardi. Flea markets are very cheap, but shopping malls are expensive, hihi! Clothes from flea markets are fine' (HS 11.1.2009). The 'hihi!' indicates giggling. In 2009, HS published a follow-up feature story on one of the first groups of Filipino nurses who had arrived in Finland eight months earlier. All three interviewees were asked to comment on their encounter with the Finnish snow and the Finnish people: 'The first snowfall was beautiful! I've seen snow only in movies before that. It was so quiet and peaceful' (HS 11.1.2009).

Colonialist language creates a narrative of people as nonbelonging, strangers, and visitors, constraining subjectivities as active claimants and agents within the professional sphere they inhabit (see also Näre \& Nordberg, 2016). Koefoed \& Simonsen (2011) relate to urban 'strangers' as relational figures, constituted in a 'spatial ambivalence between proximity and distance.' Being out-of-place, out-of-home is not only a position provided to newly arrived labor migrants but also to settled care workers through the detailed accounts of staying in touch with family and friends 'back home' and sending remittances to the home country:

She moved to Finland because she needed money to restore her house. Her 110-year old $\log$ house is in the center of Kuressaari. It accommodates both her children and her grandchild. 'It has a big veranda where we used to sit in the summer.' The house is in bad shape and they had to demolish it almost entirely. Only the walls are left. I save all my money for the renovation. (HS 18.9.2011)

In this way, notions of agency and participation offered to migrant care workers are located within the private rather than the public/professional sphere. They are actors as persons but not as professionals. As further discussed below, the blurred positioning of migrant care workers is producing unsettling rather than continuity-based scripts for migrant background care workers.

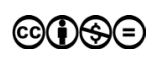




\section{Out of long-term contract}

As alluded to above, the mediascape scripts 'faces of diversity' in eldercare ambiguously. On the one hand, migrant care workers are constructed with a strong repertoire of flexible strategies on how to manage their wealth and well-being in relation to a distant 'real home', what Ong refers to as 'self-entrepreneurs' (1999). On the other hand, migrant care workers are constructed as being backward and in need of surveillance and guidance in everyday life. A study of the positioning of migrant background physicians in online discussion forums in Finland found similar paradoxes, seeing highly skilled physicians at the same time as foreign saviors and 'affect aliens', causing confusion and discomfort (Haavisto, 2014). Hence, while imaginaries in the media of the restructuring eldercare revolve around scripts of migrant care workers as 'flexible citizens' (Ong, 1999), they appear as infused with authoritative knowledge (Rose, 1999). What the media coverage downplays is that the care workers who are directly recruited from abroad are skilled nurses who have often been provided language and 'cultural' training in order to qualify as practical nurses in Finland. The print media approach care work competence predominantly as national-cultural competence, about having a realistic understanding of work and Finland, not a professional skill-demanding practice. Kuntalehti has very actively discussed the demographic challenges and the future organization of eldercare, including the shortage of care workers, driving an interesting argument about job quality in the care sector:

The challenges for human resources are first and foremost the management of workrelated stress, occupational health and wage issues. While wage levels are comparably low in the healthcare sector, the workload and responsibility are immense. Whether employees manage to continue working until the end of their careers or retire early is due to highquality personnel services and management. (Kuntalehti 20/2004)

Paradoxically, the recognition of such structural challenges in contemporary care work is not articulated in relation to the migrant background care workers, whose occupational positions rather are rather defined along the lines of cultural and linguistic capital:

The current situation calls for a special drive toward labor migration, a development that also municipalities have to take part in. There is an urge to actively seek qualified labor, which shares our basic values, from wherever available. (Kuntalehti 18/2004)

The way that migrant background care workers are scripted in the mediascape produces an imaginary of ad-hoc vagabond labor rather than of professionals who, at least potentially, could form a more long-term reciprocal contract with the care work regime as active, autonomous agents. In the empirical data, this applies to recruited care workers from abroad as well as to settled migrants. Furthermore, there are no openings in the mediascape for the upward mobility of migrant care workers in the work hierarchy. The diversifying eldercare work force is portrayed at the level of low-skilled workers, not at the level of care work management. 


\section{Discussion and Conclusion}

In earlier work, we have analyzed the ongoing glocalization of care work in Finland, resulting from policies through which the role of the state in the governance of welfare arrangements and reforms is consistently diminished (Näre \& Nordberg, 2016; Wrede et al., 2013). Decentralization of governance gives rise to new complex, multilevel processes and sets of organizations that no longer underpin uniform conceptions of skills and competences for care workers. As such, the terms of employment in the care sector are diversified. We link this transformation to a new state ideology, one focusing on urban growth and the idea of developing metropolitan regions into engines of a competitive economy, a form of 'neoliberal metropolitanism' (Wrede et al., 2013). In the mediascape, Filipino workers recruited specifically for the care sector become a kind of colonial brands or mascots of this ideology (Nordberg 2012; Näre \& Nordberg, 2016), to some extent meeting the criteria of innovation and internationalization, while the more numerous groups of migrant background care workers are silenced in the media. They are talked about, but seldom get their own voices heard.

The media is a key site for hegemonic consensual sense-making, while simultaneously offering space for counter-argumentative voices and rationales. It has been argued that neoliberal policy extends to work worlds of care through certain occupational scripts (Wrede, 2014). Such external schemata are necessarily negotiated by grass-root actors, care managers, and care workers themselves. Through analyzing the microsociological world of media discourse, we can learn about prevalent hegemonic occupational scripts and the ways in which such scripts are activated by particular actors. This analysis of how migrant background eldercare workers are positioned in the Finnish print media brought to the forefront the ways in which print media scripts enable certain migrant care worker subjectivities, while others are constrained.

It was concluded that sense-making on care, welfare, and migration in the Finnish media has not only been marked by an ethos of efficiency and flexibility but also by worker self-sufficiency in an ambiguous way. Migrant care workers are, on the one hand, constructed as an entrepreneurial, skillful, and flexible labor force, yet, on the other hand, as childish family-oriented women who are out-of-place. In these ambiguous scripts, the two rationales work together to shape public understandings of care work in ways that restrict, genderize, and racialize the 'migrant care worker' as a thin socio-cultural category, withholding equal recognition as a professional and employee.

In order to understand the ambiguity of occupational scripts in the media, it is important to recognize that different care worker subjectivities, for example, social, personal, and economic-rationalist, do not cancel each another out, but typically emerge at the same time (Miller \& Rose, 1998). In this study, these subjectivities were joined together by a broader script of individualization, neglecting structural inequalities. The flexibility of citizenship embodied in migrant eldercare worker mobility is instrumental flexibility, being useful but replaceable, in the classic way of 'buffer labor' (Wrede, 2010). Of critical concern is the individualization of the social, transferring the social conflict from the public-political context to the individual person (Ferge, 1997; Walker, 2009). Hence, at the pragmatic level of policy-making, migrant background workers risk not being voiced as full partners in labor market negotiations (see also Alho, 2013).

While this paper argues about the relevance of mediatized occupational scripts, it recognizes that subjectivities are always relational and dialogical. It is worth noting that 
alongside with the shaping of migrant care workers as flexible and grateful employees, the media simultaneously produces specific subjectivities for other key actors in the eldercare regime. Olakivi \& Niska (forthcoming 2016) show how senior professionals call for the employment of migrant care workers as an ideal solution from the point of view of the elder themselves, promising higher-quality services at lower cost (regardless of the fact that the elder cannot necessarily articulate their own needs). Drawing on such win-win rhetoric in the media (see also Edenhielm \& Rönnblom, 2012), care managers, recruitment agencies, and other actors are implicitly offered scripts as benevolent actors who are contributing to the common good in different ways.

While the legacy and ethos of an egalitarian citizenship regime is visible in the media, it is not in the meaning of redistribution within the nation-state. For migrant background care workers, social justice and equality are conditioned to global redistribution, thus conceptualized at other terms than for their coworkers. Following from such a conditional equality justice rationale, Nordic welfare state citizenship is increasingly defined according to gradations of members' rights and duties (cf. Ong, 1999). According to Aihwa Ong (1999), state power has not weakened in the era of neoliberal globalization-states have rather been transformed. In order to meet the demands of global markets, state governments provide certain privileges or restrictions to certain peoples or zones within the nation-state. Drawing on the notion of 'graduated sovereignty zones', Ong argues that the state no longer maintains a uniform governing role over its nation and national terrain (Ong, 1999: p. 215). Indeed, the analysis of flexibility needs to be taken further, following Richard's Sennett's (1998) argument about the need to ask 'flexible for whom.' While policy scripts underpin flexible terms for the global talent, in the case of migrants who are viewed as low-skilled, the flexibility tends to be available for the governments that receive them and organizations that employ them. This is an example of how limiting migration regimes build borders that extend to workplaces, limiting the agency of low-skilled workers (see Anderson 2013).

The study has shed light on the renegotiation of labor market equality and ultimately on terms of solidarity and citizenship participation. Social equality is increasingly outsourced to global rather than national redistribution in the Finnish context. The labor market political goal of full employment has been the foundation of the public economy in the Nordic welfare states. Migrant background care workers are assumed to fill the gap of labor at a time when the pool of Finnish citizens willing to work in low-paid work is decreasing. In this changing political landscape, migrant care workers constitute the new commodities, liberating Nordic women from lower level tasks in the gendered care contract. While the working life agency of migrant care workers is restricted to a particularly narrow segment of the care work world, more prestigious work roles in the care sector remain available only to nationals (Dahle \& Seeberg, 2013).

Neoliberal, particularly metropolitanist, strategies include the promotion of futureoriented innovation as well as modern images and activities (Wrede et al., 2013). Discussing de-professionalized care workers as more authentic carers justifies the deinstitutionalization of care as one important innovation. Another innovation that suggests narrow scripts for care work is the idea of replacing care with technologies and even, sometime in the future, with robots (Wrede, 2014). On the one hand, the visual images of 'new' faces and hands serving the welfare state feed this image, propelled by the media's preference for personal stories. Yet, on the other hand, in terms of gender equality, the public coverage of migrant care workers is rather rooted in the pre-welfare state-era. 
The systematic recruitment of migrant care workers sets (some) Finnish women free from the care contract, while constructing new forms of gendered and racialized divisions in the care-work worlds of the global North.

\section{Acknowledgments}

I would like to thank two anonymous referees, Laura Ahva, Cecilia Benoit, Antero Olakivi, Virpi Timonen, and Sirpa Wrede for valuable comments on previous versions of this article. The data were collected in liaison with Sandra Torres and Jonas Lindblom as part of a Swedish-Finnish research collaboration on media, ethnicity, and eldercare. The research was funded by the Academy of Finland (projects number 1273392 and 251239).

\section{References}

Alho, R. (2013) Inclusion or Exclusion? Trade Union Strategies and Labour Migration. Tur$\mathrm{ku}$ : Institute of Migration.

Appadurai, A. (1990) Disjuncture and difference in the global cultural economy, pp. 295310 in M. Featherstone (ed) Global Culture: Nationalism, Globalisation and Modernity, London: Sage.

Anderson, B. (2007) A very private business. Exploring the demand for migrant domestic workers, European Journal of Women's Studies, 14(3): 247-264. doi: http://dx.doi. org/10.1177/1350506807079013.

Anderson, B. (2013) Us and them: The dangerous politics of immigration control. Oxford: OUP.

Anttonen, A. and Häikiö, L. (2011) Care 'going market': Finnish elderly-care policies in transition, Nordic Journal of Social Research, 2: 1-21. doi: http://dx.doi.org/10.15845/njsr. v2i0.111.

Brennan, D., Cass, B., Himmelweit, S. and Szebehely, M. (2012). The marketisation of care: rationales and consequences in Nordic and liberal care regimes, Journal of European Social Policy, 22(4): 377-391. doi: http://dx.doi.org/10.1177/0958928712449772.

Cameron, C. and Boddy, J. (2006) Knowledge and education for care workers: what do they need to know? pp. 34-49 in J. Boddy, C. Cameron and P. Moss (eds) Care Work: Present and Future, London and New York: Routledge.

Carmel, E. (2011) European Union Migration Governance: utility, security and integration, pp. 49-66 in E. Carmel, A. Cerami and T. Papadopoulos (eds) Migration and Welfare in the New Europe, Bristol: Policy Press.

Cheng, S-J. (2004) Contextual politics of difference in transnational care: the rhetoric of Filipina domestics' employers in Taiwan, Feminist Review, 77: 46-64.

Dahl, HV. (2012) Neo-liberalism meets the Nordic welfare state: gaps and silences, NORA, 20(4): 283-288. doi: http://doi.org/10.1080/08038740.2012.747790.

Dahle, R. and Seeberg, ML. (2013) 'Does she speak Norwegian?' Ethnic dimensions of hierarchy in Norwegian healthcare workplaces, Nordic Journal of Migration Research, 3(2): 82-90. doi: http://doi.org/10.2478/v10202-012-0018-4.

Dean, M. (1994) A social structure of many souls: moral regulation, government, and self-formation, Canadian Journal of Sociology, 19(2): 145-168. doi: http://dx.doi.org/ $10.2307 / 3341342$. 
Dobrowolsky, A. and Jenson, J. (2004) Shifting representations of citizenship: Canadian politics of 'women' and 'children', Social Politics, 11(2): 154-180. doi: http://dx.doi. org/10.1093/sp/jxh031.

Doyle, M. and Timonen, V. (2009) The different faces of care work: understanding the experiences of the multi-cultural care workforce, Ageing and Society, 29(3): 337-350, doi: http://doi.org/10.1017/S0144686X08007708.

Edenhielm, S. and Rönnblom, M. (2012) Tracking down politics and power in neo-liberal society, NORA, 20(4): 227-229. doi: http://dx.doi.org/10.1080/08038740.2012.747785.

Edlund, J. and Johansson Sevä, I. (2013) Is Sweden being torn apart? Privatization and old and new patterns of welfare state support, Social Policy \& Administration, 47(5): 542564. doi: http://dx.doi.org/10.1111/spol.12021.

Ferge, Z. (1997) The changed welfare paradigm: the individualization of the social, Social Policy \& Administration, 31(1): 20-44. doi: http://dx.doi.org/10.1111/1467-9515.00035.

Fraser, N. (2007) Transnationalizing the public sphere: on the legitimacy and efficacy of public opinion in a post-Westphalian world, Theory, Culture \& Society, 24(4): 7-30. doi: http://dx.doi.org/10.1177/0263276407080090.

Haavisto, C. (2014) Positioning migrant physicians as Dr. Horror and Dr. Nice: a study of status and affect in online discussion forums, Nordic Journal of Migration Research, 4(1): 21-29. doi: http://dx.doi.org/10.2478/njmr-2014-0001.

Hanafi, S. (2012) Flexible citizenship and the inflexible nation-state: new framework for appraising the Palestinian refugees' movements, Journal of International Migration and Integration, 13(4): 441-458. doi: http://dx.doi.org/10.1007/s12134-011-0198-0.

Hasenfeld, Y. and Garrow, EE. (2012) Nonprofit human service organizations, social rights, and advocacy in a neoliberal welfare state, Social Service Review, 82(2): 1-28. doi: http://dx.doi.org/10.1086/666391.

Hendriks, F. and Tops, P. (1999) Between democracy and efficiency: trends in local governmental reform in the Netherlands and Germany, Public Administration, 77(1): 133-153. doi: http://dx.doi.org/10.1111/1467-9299.00147.

Hochschild, AR. (2000) Global care chains and emotional surplus value, pp. 130-46 in W. Hutton and A. Giddens (eds) On the Edge: Living with Global Capitalism, London: Jonathan Cape.

Hvinden, B. and Johansson, H. (eds) (2007) Citizenship in Nordic Welfare States - Dynamics of Choice, Duties and Participation in a Changing Europe. New York: Routledge.

Häikiö, L. (2010) The diversity of citizenship and democracy in local public management reform, Public Management Review, 12(3): 363-384. doi: http://dx.doi.org/10.1080/ 14719030903286649.

Isaksen, LW. (ed) (2010) Global Care Work: Gender and Migration in Nordic Societies, Lund: Nordic Academic Press.

Kamp, A. and Hvid, H. (2012) Elderly Care in Transition: Management, Meaning, and Identity at Work: a Scandinavian Perspective, Copenhagen: Copenhagen Business School Press.

Kananen, J. (2014) The Nordic Welfare State in Three Eras: From Emancipation to Discipline, Farnhamn: Ashgate.

Kananen, J. (2012) Nordic paths from welfare to workfare: Danish, Swedish and Finnish Labour market reforms in comparison, Local Economy, 27(5-6): 558-576. doi: http://dx.doi.org/10.1177/0269094212445351.

Kantola, A. and Kananen, J. (2013) Seize the moment: financial crisis and the making of the Finnish competition state, New Political Economy, 18(6): 811-826. doi: http://dx.doi.or $\mathrm{g} / 10.1080 / 13563467.2012 .753044$.

Keskinen, S. (2009) 'Honour-related violence' and Nordic nation-building, pp. 257-72 in S. Keskinen, S. Tuori, S. Irni and D. Mulinari (eds) Complying with Colonialism: Gender, Race and Ethnicity in the Nordic Region. Farnham: Ashgate. 
Kettunen, P. (2014) Conflicts and compromises in the Nordic pattern of social regulation, pp. 96-121 in P. Kettunen, S. Kuhnle and Y. Ren (eds) Reshaping Welfare Institutions in China and the Nordic Countries, Helsinki: NordWel.

Kettunen, P. (2012) Reinterpreting the historicity of the Nordic model, Nordic Journal of Working Life Studies, 2(4): 21-43. doi: http://dx.doi.org/10.19154/njwls.v2i4.2303.

Kettunen, P. (2011) The transnational construction of national challenges: the ambiguous Nordic model of welfare and competitiveness, pp. 16-40 in P Kettunen and K Pedersen (eds) Beyond Welfare State Models. Transnational Historical Perspectives on Social Poli$c y$, Cheltenham: Edwar Elgar.

Koefoed, LM. and Simonsen, K. (2011) 'The stranger', the city and the nation: on the possibilities of identification and belonging, European Urban and Regional Studies, 18(4): 343-357. doi: http://dx.doi.org/10.1177/0969776411399343.

Koopmans, R., Statham P., Giugni M. and Passy F. (2005) Contested Citizenship: Immigration and Cultural Diversity in Europe, Minneapolis: University of Minnesota Press.

Kröger, T. (2011) The adoption of market-based practices within care for older people: is the work satisfaction of Nordic care workers at risk? Nordic Journal of Social Research, 2(1): 91-103. doi: http://dx.doi.org/10.15845/njsr.v2i0.114.

Lamont, M, Welburn, J. and Fleming, C. (2013) Responses to discrimination and social resilience under neoliberalism: The United States compared, pp. 129-157 in PA Hall and M Lamont (eds) Social Resilience in the Neoliberal Age, Social Resilience in the Neoliberal Age, Cambridge: Cambridge University Press.

Laurén, J. and Wrede, S. (2008) Immigrants in care work: ethnic hierarchies and work distribution, Finnish Journal of Ethnicity and Migration, 3(3): 20-31.

Laliberte Rudman, D. (2006) Shaping the active, autonomous and responsible modern retiree: an analysis of discursive technologies and their links with neo-liberal political rationality, Ageing and Society, 26(2): 181-201. doi: http://dx.doi.org/10.1017/s0144686x05004253.

Levitt, P. and Glick Schiller, N. (2004) Conceptualizing simultaneity: a transnational social field perspective on society, International Migration Review, 38(3): 1002-1039. doi: http://dx.doi.org/10.1111/j.1747-7379.2004.tb00227.x.

Lin, W. (2012) Beyond flexible citizenship: towards a study of many Chinese transnationalisms, Geoforum, 43(1): 137-146. doi: http://dx.doi.org/10.1016/j.geoforum.2011.07.011.

Livingstone, S. (2009) On the mediation of everything: ICA presidential address 2008. Journal of Communication, 59(1): 1-18. doi: http://dx.doi.org/10.1111/j.1460-2466.2008.01401.x.

Lutz, H. and Möllenbeck-Palenga, E. (2012) Care workers, care drain and care chains: reflections on central perceptions in the debate about care and migration, Social Politics, 19(1): 15-37. doi: http://dx.doi.org/10.1093/sp/jxr026.

Lutz, H. (ed) (2008) Migration and Domestic Work: A European Perspective on a Global Theme, Aldershot: Ashgate.

McCombs, M. (2004) Setting the Agenda: The mass media and public opinion, Cambridge, UK: Polity Press.

Miller, P. and Rose, N. (2008) Governing the Present. Administering Economic, Social and Personal Life, Cambridge: Polity Press.

Muuri, A. and Manderbacka, K. (2010) Hyvinvointivaltion kannatusperusta (Welfare state legitimacy), pp. 96-110 in M. Vaarama, P. Moisio and S. Karvonen (eds) Suomalaisten hyvinvointi (The wellbeing of the Finnish population), Helsinki: Yliopistopaino.

Nordberg, C. (2004) Legitimising immigration control: Romani asylum-seekers in the Finnish Debate, Journal of Ethnic and Migration Studies, 30(4): 717-735. doi: http://dx.doi.org/ 10.1080/13691830410001699531.

Nordberg, C. (2007) Claiming citizenship: marginalised voices on identity and belonging. Citizenship Studies, 10(5): 523-539. doi: http://dx.doi.org/10.1080/13621020600954952. 
Nordberg, C. (2012) Localising global care work: a discourse on migrant care workers in the Nordic welfare regime, pp. 63-78 in G. Boucher and A. Gridsted (eds) Transnationalism in the Global City. Deusto: University of Deusto (EDMIDI).

Nordberg, C. (2015) Dynamics of recognition: minority ethnic access to transformative power in the Nordic welfare state, pp. 91-109 in P. Kivisto and P. Kraus (eds) The Challenge of Minority Integration Politics and Policies in the Nordic Nations, De Gruyter Open. doi: http://dx.doi.org/10.1515/9783110441116-007.

Näre, L. (2013) Migrancy, gender and social class in domestic and social care labour in Italy: an intersectional analysis of demand, Journal of Ethnic and Migration Studies, 39(4): 601-623. doi: http://dx.doi.org/10.1080/1369183x.2013.745238.

Näre, L. and Nordberg, C. (2016) Neo-liberal post-colonialism in the media: constructing Filipino nurse subjects in Finland, European Journal of Cultural Studies, 19(1): 16-32. doi: http://doi.org/10.1177/1367549415585557.

Olakivi, A. (2013) 'In case you can speak finnish, there's no problem': reconstructing problematic identity-positions in migrant care workers' organisational discourse, Nordic Journal of Migration Research, 3(2): 91-99. doi: http://doi.org/10.2478/v10202-012-0019-3.

Olakivi, A. and Niska, M. (forthcoming, 2016) Constructing home-likeness: migrant caregivers and the politics of 'activation' in public care provision in Finland, in K. Walsh and L. Näre (eds) Transnational Migration and Home in Older Age, Routledge: London.

Ong, A. (1996) Cultural citizenship as subject-making, Current Anthropology, 37(5): 737762.

Ong, A. (1999) Flexible Citizenship, Durham, NC: Duke University Press.

Ong, A. (2007) Neoliberalism as a mobile technology, Transactions of the Institute of British Geographers, 32: 3-8. doi: http://dx.doi.org/10.1111/j.1475-5661.2007.00234.x.

Parreñas, RS. (2001) Servants of Globalization: Women, Migration, and Domestic Work, Stanford, CA: Stanford University Press.

Pöyhtäri, R. (2014) Immigration and Ethnic Diversity in Finnish and Dutch Magazines: Articulations of Subject Positions and Symbolic Communities, Tampere: Tampere University Press.

Rantanen, T. (2005) Media and Globalization, Sage: London.

Rose, N. (1999) Powers of Freedom: Reframing Political Thought, University of Cambridge, Cambridge.

van Riemsdijk, M. (2010) Neoliberal reforms in elder care in Norway: roles of the state, Norwegian employers and Polish nurses, Geoforum, 41(6): 930-939. doi: http://dx.doi. org/10.1016/j.geoforum.2010.06.008.

Sajoo, AB. (2008) Introduction, pp. 1-25 in AB. Sajoo (ed) Muslim Modernities: Expressions of the Civil Imagination, London: IB Tauris \&co.

Sennett, R. (1999) The Corrosion Of Character. The Personal Consequences Of Work in The New Capitalism, New York: WW Norton.

Stenius, H. (1982) Massorganisation och nationell sammanhållning (Collective organization and national solidarity), Sosiologia, 2: 112-124.

Sowards, S. and Pineda, R. (2013) Immigrant narratives and popular culture in the United States: border spectacle, unmotivated sympathies, and individualized responsibilities, Western Journal of Communication, 77(1): 72-91. doi: http://dx.doi.org/10.1080/1057 0314.2012.693648.

Svallfors, S. (2013) Trygg, stöttande, tillitsfull? Svenskarna och välfärdsstaten (Safe, Supportive and Trustworthy? The Swedes and the Welfare State), pp. 323-333 in H. Swärd, PG. Edebalk and E. Wadensjö (eds) Vägar till välfärd (Paths to Welfare). Stockholm: Liber.

ter Wal, J. (ed.) (2002) Racism and Cultural Diversity in the Mass Media, Vienna: EUMC. 
Torres, S., Lindblom, J \& Nordberg, N. (2014) Daily newspaper reporting on elder care in Sweden and Finland: a quantitative content analysis of ethnicity- and migration- related issues, Vulnerable Groups and Inclusion, 5: 1-21. doi: http://dx.doi.org/10.3402/vgi. $\mathrm{v} 5.21260$.

Trädgårdh, L. (ed) (2006) The State \& Civil Society in Northern Europe: The Swedish Model Reconsidered, New York: Berghans books.

Yeates, N. (2009) Globalising Care Economies and Migrant Workers: Explorations in Global Care Chains, Houndmills: Palgrave Macmillan.

Vabø, M. (2009) Home care in transition. The complex dynamic of competing drivers of change in Norway, Journal of Health Organization and Management, 23(3): 346-359. doi: http://dx.doi.org/10.1108/14777260910966762.

Van Dijk, T.A. (1991) Racism and the Press, London: Routledge.

Van Dijk, T.A. (1988) News as Discourse, London: Academic Press.

Walker, A. (2009) Ageing and social policy: theorizing the social, pp. 595-614 in V. Bengtson, M. Silverstein, N. Putney and D. Gans (eds) Handbook of Theories of Ageing, New York: Springer.

Williams, J.F. (2012) Converging variations in migrant care work in Europe, Journal of European Social Policy, 20.4: 363-376. doi: http://doi.org/10.1177/0958928712449771.

Wrede, S. (2014) How Marketisation Policies Challenge Professionalism of Care in Western Europe: Subservient Past, Subservient Future for the Care Workforce? Keynote lecture at the 15th Biennial Conference of the European Society for Health and Medical Sociology, August 28-30, 2014, Helsinki, Finland.

Wrede, S. and Näre, L. (2013) Glocalising care in the Nordic countries: an introduction to the special issue, Nordic Journal of Migration Research, 3(2): 57-62. doi: http://dx.doi. org/10.2478/v10202-012-0015-7.

Wrede, S., Näre, L., Olakivi, A. and Nordberg, C. (2013) Neoliberal Metropolitanism and the Nordic Welfare State: Paradoxes of (In)equality in the Care Work Regime', paper presented at the 2013 American Sociological Association Annual Meeting, August 13, 2013.

\section{Notes}

1 When using the notion of 'migrant care workers', it is a simplification referring to different categories of migrant background care workers: individuals who have been recruited from abroad for care work tasks as well as settled migrants employed and/or trained as care workers. Some of the workers portrayed as 'migrants' in the media may be permanent residents in Finland and have even been granted Finnish citizenship, while still categorized according to their migrant background.

2 In Finnish: vanhu*, maahanm*, etni*, vähemmistö*, ulkoma*, kulttuuri*, kieli*, monikulttuuri*, moninaisuu*, siirtolai*.

${ }^{3}$ During the years 2003-2005, 21 issues, 2006-2008, 20 issues, 2009-2010, 18 issues, and 2011-2013, 15 issues annually. 